\title{
Profile of atacicept and its potential in the treatment of systemic lupus erythematosus [Corrigendum]
}

\author{
Cogollo E, Silva MA, Isenberg D. Drug Design, Develop- \\ ment and Therapy. 2015;9:1331-1339.
}

The author list contained a spelling error: Estafania Cogollo should be Estefania Cogollo.

On page 1337, first column: "Only two patients reached $\operatorname{IgG}$ levels below $3 \mathrm{~g} / \mathrm{L}$ and, even in those, no serious infections were reported. Of note, the infections in the two patients who died were not associated with hypergammaglobulinemia" - "hypergammaglobulinemia" should be "hypogammaglobulinemia".

On page 1337, second column: "Furthermore, hypergammaglobulinemia has been reported in approximately half of renal transplant patients who received MMF and steroids and an increased risk of infection has been observed in other LN studies during the induction phase with MMF and high-dose CS" - "hypergammaglobulinemia" should be "hypogammaglobulinemia".

\section{Publish your work in this journal}

Drug Design, Development and Therapy is an international, peerreviewed open-access journal that spans the spectrum of drug design and development through to clinical applications. Clinical outcomes, patient safety, and programs for the development and effective, safe, and sustained use of medicines are a feature of the journal, which has also been accepted for indexing on PubMed Central. The manuscript management system is completely online and includes a very quick and fair peer-review system, which is all easy to use. Visit http://www.dovepress.com/testimonials.php to read real quotes from published authors.

\footnotetext{
Submit your manuscript here: http://www.dovepress.com/drug-design-development-and-therapy-journal
}

submit your manuscript $\mid$ www.dovepress.com

Dovepress

http://dx.doi.org// 0.2147/DDDT.S84395 